\title{
Phytoremediation of heavy metal polluted soil and water in Vietnam
}

\author{
Sủ dụng thực vật để xử lý ô nhiêm kim loại nặng trong đất và nuớc tại Việt Nam \\ Research article
}

Bui, Thi Kim Anh ${ }^{1}$; Dang, Dinh Kim ${ }^{1}$; Nguyen, Trung Kien ${ }^{1}$; Nguyen, Ngoc Minh ${ }^{2}$; Nguyen, Quang Trung ${ }^{1}$; Nguyen, Hong Chuyen ${ }^{1}$

${ }^{1}$ Institute of Environmental Technology, VAST, 18 Hoang Quoc Viet, Cau Giay, Hanoi, Vietnam; ${ }^{2}$ VNU University of Science, 334-Nguyen Trai, Hanoi, Viet Nam

\begin{abstract}
Phytoremediation has been intensively studied during the past decade due to its cost-effectiveness and environmental harmonies. Most of the studies on treatment of heavy metal pollution in soil and water by plant species have been done in developed countries but are limited in Vietnam. In this study, we presented some research results of phytoremediation of polluted soils and water with heavy metals that were done by Institute of Environmental Technology for several last years. For treatment of heavy metal pollution in the water, some plants have great ability to accumulate heavy metals such as Vetiveria zizanioides, Phragmites australis, Eichhornia crassipes, Pistia stratiotes, Ipomoea aquatica, Nypa fruticans and Enhydra fluctuans. The heavy metal uptake into shoots and roots of 33 indigenous plant species in Thai Nguyen province was also determined. Two species of the plants investigated, Pteris vittata L. and Pityrogramma calomelanos L. were As hyperaccumulators, containing more than $0.1 \%$ As in their shoots while Eleusine indica, Cynodon dactylon, Cyperus rotundus and Equisetum ramosissimum accumulated very high $\mathrm{Pb}$ $(0.15-0.65 \%)$ and $\mathrm{Zn}(0.22-1.56 \%)$ concentrations in their roots. Some experiments to clarify the potential of several plants as good candidates for phytoremediation of polluted soil by heavy metals were carried out in our institute.
\end{abstract}

Phương pháp sử dung thực vật để xủ̉ lý ô nhiễm đã được nghiên cứu nhiều trong thập kỷ qua do chi phi thấp và thân thiện với môi truờng. Hầu hết các nghiên cứu về xủ lý ô nhiếm kim loại nặng trong đất và nước bằng thực vật đã được thực hiện ở các nước phát triển nhung it có tại Việt Nam. Trong nghiên cứu này, chúng tôi giới thiệu một số kết quả dùng công nghệ thực vật để xủ lý ô nhiếm kim loại nặng trong đất và nuớc tại Viện Công nghệ môi truờng trong những năm gần đây. Đối với xủ lý ô nhiếm kim loại nạng trong nuớc, một sổ thực vật có khả năng tích lũy tốt kim loại năng nhu Vetiveria zizanioides, Phragmites australis, Eichhornia crassipes, Pistia stratiotes, Ipomoea aquatica, Nypa fruticans và Enhydra fluctuans. Sụ hấp thu và tích lũy kim loại nặng trong phần trên mặt đất và rễ của 33 loài thực vật bản địa tại Thái Nguyên cũng đã được xác định. Hai loài thực vật khảo sát là Pteris vittata và Pityrogramma calomelanos là nhũng loài siêu tích lũy As, chứa hơn 0,1\% As trong phần trên mặt đất của cây. Eleusine indica, Cynodon dactylon, Cyperus rotundus và Equisetum ramosissimum tích lũy $P b(0,15-0,65 \%)$ và $\mathrm{Zn}(0,22-$ 1,56\%) rất cao trong rễ. Một số thí nghiệm đánh giá tiềm năng của một số thực vật là đối tuợng tốt cho xư lý ô nhiếm kim loại nặng trong đất đã được tiến hành trong phòng thi nghiệm của Viện Công nghệ môi truờng.

Keywords: phytoremediation, heavy metals, pollution, potential plant

\section{Introduction}

Pollution of soil and water is now a global problem and attracted attention of many countries due to its harmful effects with many aspects of environment and human life.
In Viet Nam, heavy metal pollution has been identified in many locations including urban areas as well as rural and mountainous ones. For example, in Hanoi, Van Dien industrial zone including Van Dien Batteries factory, Synthetic Paint factory, Van Dien Phosphate Company and also Orion Hanel industrial zone have high risk of 
lead contamination (Le Hien Thao, 2004). The contamination in traditional villages is also an urgent problem. There are about 1450 traditional villages, based on the survey results of 52 typical villages, of which $100 \%$ surveyed villages had caused environmental pollution. Typically, the village recycling lead from batteries of Chi Dao commune, Van Lam district, Hung Yen province has 25 lead production units. Every day, this commune produces 10 tons of lead and generates about 1 ton of toxic dust (Dang Kim Chi et al., 2005). During the production, traditional villages released a large amount of significantly toxic chemicals into the environment via wastewater including many heavy metals such as $\mathrm{Fe}, \mathrm{Cr}, \mathrm{Ni}, \mathrm{Zn}$, and $\mathrm{CN}$. Mineral exploiting and processing industry discharge highly toxic substances such as $\mathrm{Cd}, \mathrm{Pb}, \mathrm{Zn}, \mathrm{Cu}$, As (Le Van Thanh et al, 2004). The average As concentration in waste stone samples was of $5000 \mathrm{mg} / \mathrm{kg}$, exceeding the allowable standard of heavy metal in the soil many times. The concentration of other heavy metals in the stone samples were also very high (Cu: $1260 \mathrm{mg} / \mathrm{kg}$; Pb: $105 \mathrm{mg} / \mathrm{kg}$; Cd: $0.5 \mathrm{mg} / \mathrm{kg}$; Se: $17 \mathrm{mg} / \mathrm{kg}, .$. ) (Tiberon mineral company, 2004). In some communes of Ha Nam province, $94.4 \%$ wells water samples had very high As concentration, with was exceeded national technical regulation on drinking water quality (Pham Hung Viet et al., 2004).

There are many methods for treating heavy metal pollution. Although physicochemical methods are effective, they are complex, expensive, not environmental friendly and difficult to be applied on a large scale. Phytoremediation is cost effective, environmental friendly and most suitable for developing countries (Ghosh et al., 2005). At present, more than 500 plant species of metal and metalloid hyperaccumulators have been reported in literatures (Hemen Sarma, 2011).

Phytoremediation of polluted soil and water is soon studied in many countries (Salt DE et al., 1995, Raskin I. et al., 1997, E. Lombi et al., 2001). However, in Viet Nam, this study has been started only in recent years and its practical application is still limited. Le Van Cat et al. (2008) researched on $\mathrm{NH}_{4}^{+}$and As removal capability from contaminated water by Typha latifolia, Canna and Pennisetum purpureum. Le Duc et al. (2005) studied on $\mathrm{Pb}$ uptake of Ipomoea aquatica, Eichhornia crassipes and Brassica juncea. Dang Thi An et al. (2007) identified heavy metal concentrations of some vegetables. Tran Kong Tau et al. (2005) indicated the accumulation ability of $\mathrm{Cd}$ and $\mathrm{Zn}$ in Calendula officinalis, Acanthopanax aculeatus. Tran Van Tua et al. (2008) researched on the tolerance and accumulation of $\mathrm{Pb}, \mathrm{Cd}, \mathrm{Cr}, \mathrm{Ni}$ and $\mathrm{Zn}$ in some plant species. Diep Thi My Hanh et al. (2007) investigated the $\mathrm{Pb}$ accumulation of Lantana camara. In this paper, we present some research results of phytoremediation for polluted soil and water with heavy metals.

\section{Materials and methods}

\subsection{Plant species}

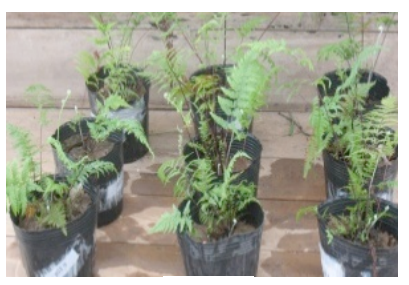

a

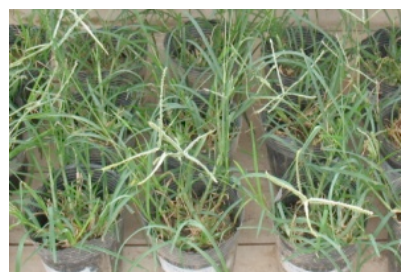

c

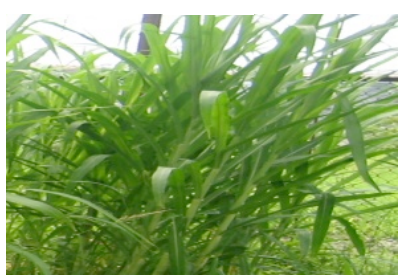

e

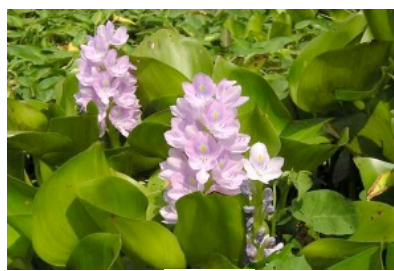

g

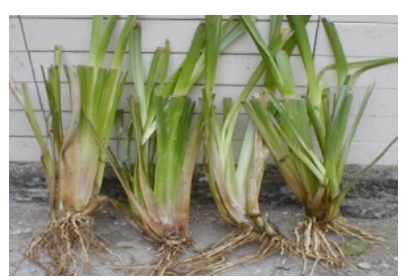

$\mathrm{h}$

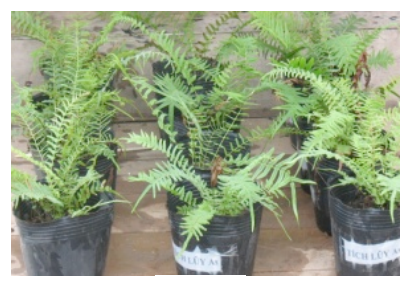

b

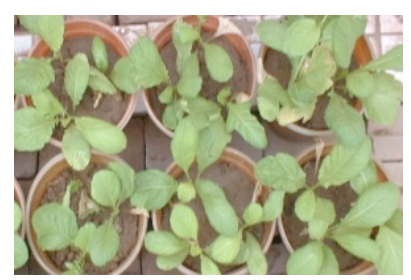

d

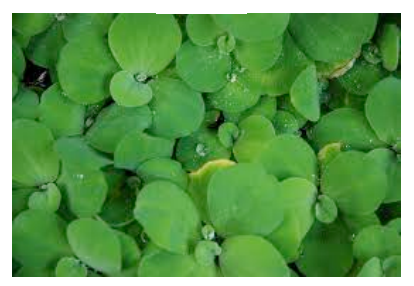

f

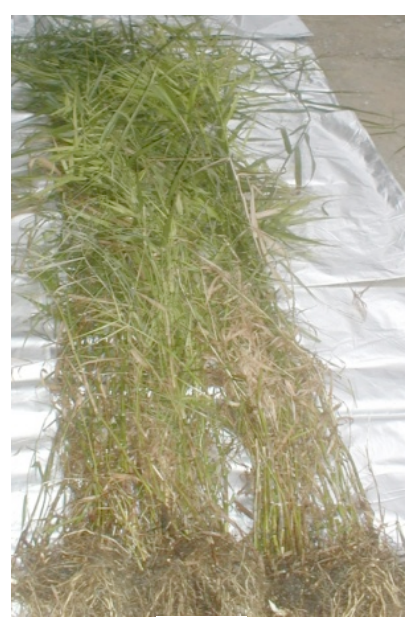

i
Figure 1. Plant species used in our experiments (a) Pityrogramma calomelanos; (b) Pteris vittata; (c) Eleusine indica; (d) Brassica juncea; (e) Pennisetum purpureum; (f) Pistia stratiotes; (g) Eichhornia crassipes; (h) Vetiveria zizanioide; (i) Phragmites australis.

\section{Results and discussions}

\subsection{Heavy metal removal from water by plants}

By experimental studies, we have demonstrated heavy metal uptake and accumulation in some aquatic plant species. For example, Eichhornia crassipes was likely to 
absorb $\mathrm{Pb}, \mathrm{Cr}, \mathrm{Ni}, \mathrm{Zn}$ and $\mathrm{Fe}$ in industrial waste water, Nasturtium officinale L. could remove $\mathrm{Cr}$ and $\mathrm{Ni}$ from electroplating wastewater. Meanwhile, Ceratophyllum demersum L., Salvinia cucullata were likely to reduce Fe, $\mathrm{Cu}, \mathrm{Pb}$ and $\mathrm{Zn}$ in Bay Mau lake, Hanoi.

The evaluation on ability to remove $\mathrm{Cr}, \mathrm{Ni}$ in water of some plant species has been done. The plant species were capable of removing $\mathrm{Cr}$ and $\mathrm{Ni}$ from contaminated water. The experiments on tolerance of 7 plant species were evaluated. Plant was washed and grown in clean water before 3 days experimental set-up. There were seven treatments sets with five replicates for each. Each plastic pot contained 6 liter water medium, with 70 gram fresh weight (FW) plant. $\mathrm{Cr}$ and $\mathrm{Ni}$ concentrations in each pot were $1,3,5,7$ and $10 \mathrm{mg} / 1$. Preparing $\mathrm{Cr}^{6+}, \mathrm{Cr}^{3+}$ and $\mathrm{Ni}^{2+}$ sollutions by adding $\mathrm{K}_{2} \mathrm{Cr}_{2} \mathrm{O}_{7}, \mathrm{CrCl}_{3} .6 \mathrm{H}_{2} \mathrm{O}$ and $\mathrm{NiSO}_{4} .7 \mathrm{H}_{2} \mathrm{O}$, respectively. After 14 days experiment, the investigated plants were harvested and then washed with tap water to remove dust, rinsed with deionized water, and kept for 10 hour to evaluate the plant fresh weight. The results showed that the tolerance of these species can be arranged in the following order: Vetiveria zizanioides $>$ Phragmites australis $>$ Eichhornia crassipes $>$ Pistia stratiotes > Ipomoea aquatica > Nypa fruticans > Enhydra fluctuans. A treating system of $\mathrm{Cr}$ and $\mathrm{Ni}$ in contaminated water was established at pilot scale by "root zone" technology. Two plant species having high tolerance to $\mathrm{Cr}$ and $\mathrm{Ni}$ (Vetiveria zizanioides and Phragmites australis) were selected for further studies in pilot scale $\left(0.5 \mathrm{~m}^{3} \cdot\right.$ day $\left.^{-1}\right)$. This system worked continuously in 23 weeks (Inlet wastewater is a mixture of electroplating wastewater contained $\mathrm{Cr}$ and $\mathrm{Ni}$ and animal husbandry wastewater). This inlet wastewater

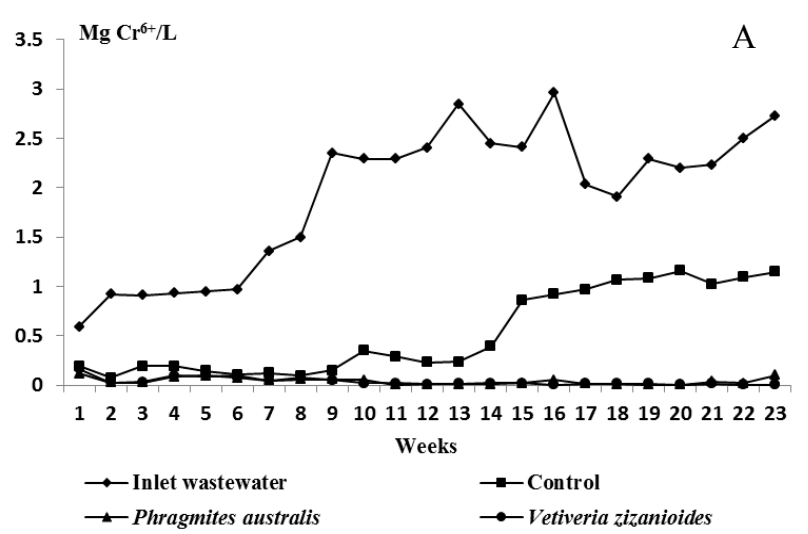

contained average concentrations of $\mathrm{Cr}^{6+}, \mathrm{Cr}^{3+}, \mathrm{Ni}^{2+}$, COD, T-N as T-P as follows: 1.9, 3.2, 3.88, 111.4, 42 and $8 \mathrm{mg} / \mathrm{l}$, respectively.

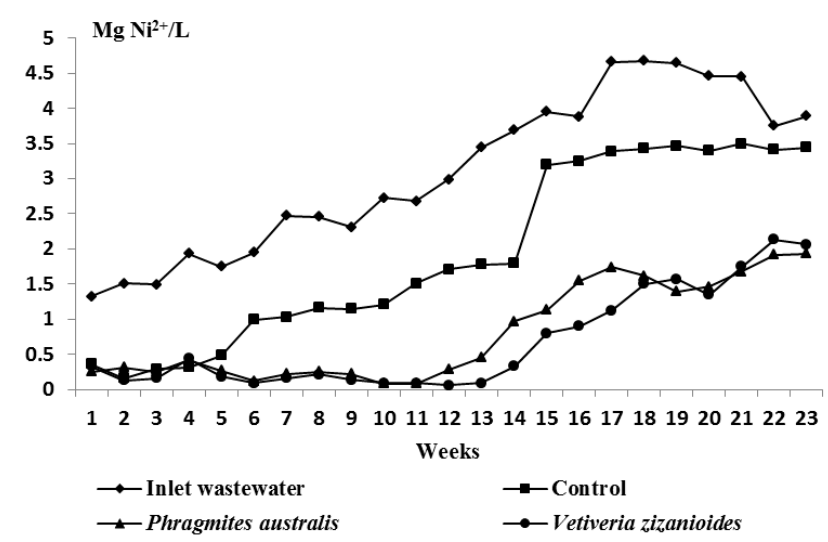

Figure 2. $\mathrm{Ni}^{2+}$ removing capacity of Vetiveria zizanioides and Phragmites australis

Treatment system consists of 03 cement tanks. Each tank can contain $0.5 \mathrm{~m}^{3}$ water with rock in the bottom and sand at the top. Control tank has no plant. The tanks growing Vetiveria zizanioides and Phragmites australis have plant density as $10 \mathrm{~cm} \times 15 \mathrm{~cm}$. Each tank has 108 plants, fresh weight of each branch is of 60 gram FW. After 23 weeks experiment at pilot scale, $\mathrm{Ni}$ treatment efficiencies of Vetiveria zizanioides, Phragmites australis and control reached $91.5 \%, 88.4 \%$ and $49.68 \%$, respectively. Concentration of $\mathrm{Ni}^{2+}$ in outlet of the control, Vetiveria zizanioides and Phragmites australis were 1.95, 0.33 and $0.45 \mathrm{mg} / \mathrm{l}$, respectively (Figure 2 ).

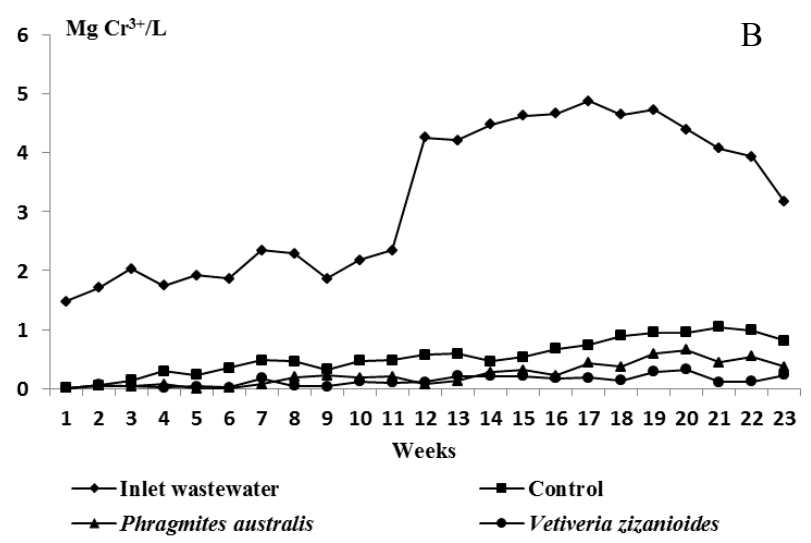

Figure 3: $\mathrm{Cr}^{6+}$ (A) and $\mathrm{Cr}^{3+}$ (B) removing capacity of Vetiveria zizanioides and Phragmites australis

After 23 weeks experiment at pilot scale, $\mathrm{Cr}^{6+}$ treatment efficiencies of Phragmites australis and Vetiveria zizanioides were very high reaching $97.97 \%$ and $98.12 \%$, respectively [Fig.3]. The $\mathrm{Cr}^{6+}$ concentration in inlet wastewater of 2 treatments was $1.92 \mathrm{mg} / \mathrm{L}$, whereas the $\mathrm{Cr}^{6+}$ concentration in outlet of Vetiveria zizanioides and Phragmites australis tank were 0.053 and $0.047 \mathrm{mg} / \mathrm{L}$ respectively. The inlet $\mathrm{Cr}^{3+}$ concentration of Vetiveria zizanioides and Phragmites australis tank was 3.218 $\mathrm{mg} / \mathrm{l}$, outlet of Vetiveria zizanioides and Phragmites were 0.2 and $0.24 \mathrm{mg} / 1$, respectively. The treatment efficiencies by Vetiveria zizanioides and Phragmites australis were
$95.91 \%$ and $92.6 \%$, respectively. The outlet concentrations of $\mathrm{Cr}^{6+}$ and $\mathrm{Cr}^{3+}$ were under the limitation for industrial wastewater according to Vietnam standard (TCVN 5945-2005).

\subsection{Heavy metal removal from soil by plants}

\subsubsection{Screening potential plants for heavy metal removal}

A total of 33 different plant species samples were collected from four mining areas in Thai Nguyen 
province to identify the heavy metal concentrations in their roots and shoots. The collected plant species can grow at the mine tailings or in the soils affected by mining waste. The results showed that 2 ferns, Pteris vittata L. and Pityrogramma calomelanos L. were capable of accumulating high arsenic concentrations. As concentrations in shoot and root of Pteris vittata L. were $5876.5 \pm 99.6$ and $2642.5 \pm 72.3 \mathrm{mgkg}^{-1}$, respectively; while these figures of Pityrogramma calomelanos L. were $2426.3 \pm 104.5$ and $2256 \pm 123.4 \mathrm{mgkg}^{-1}$. Remarkably, a large amount of As from roots of these ferns was transposed to shoot, facilitating the removal of As from contaminated soil. The $\mathrm{Zn}$ accumulating ability in some investigated plant species was quite high, e.g. Equisetum ramosissimum, Cyperus rotundus. and Eleusine indica. with $\mathrm{Zn}$ accumulated in shoots at $1346.2 \pm 130.2$, $1201.4 \pm 147.3$ and $4346.8 \pm 157.9 \mathrm{mgkg}^{-1}$, respectively and in roots at $3756.9 \pm 145.7,2194.4 \pm 155.7$ and $3108.7 \pm 213.5$ $\mathrm{mgkg}^{-1} \mathrm{Zn}$, respectively. Our finding in Thai Nguyen province indicates that, two ferns Pteris vittata L. and Pityrogramma calomelanos L. are suitable for As treatment in the mining soil of $\mathrm{Ha}$ Thuong, Dai $\mathrm{Tu}$ district, four grasses Eleusine indica, Cynodon dactylon, Cyperus rotundus and Equisetum ramosissimumare the best at keeping $\mathrm{Pb}, \mathrm{Zn}$ concentrations in their root. So we can use these grasses for phytostabilization of $\mathrm{Pb}$ and $\mathrm{Zn}$ in Tan Long, Dong Hy district.

Based on the screening results, we carried out some experiment concerning with the potential plants as good candidates for phytoremediation of heavy metal polluted soil.

\subsubsection{Brassica juncea}

$\mathrm{As}, \mathrm{Pb}$ and $\mathrm{Cd}$ accumulations of Brassica juncea were quite good. All 3 heavy metals $(\mathrm{Cd}, \mathrm{As}$ and $\mathrm{Pb})$ can be accumulated in roots more than in the shoots. In trace concentration, the heavy metals can stimulate plant growth but with higher concentrations $(\mathrm{Cd}>25 \mathrm{ppm}, \mathrm{As}>$ $200 \mathrm{ppm}$ and $\mathrm{Pb}$ from 2000 to $3000 \mathrm{ppm}$ ) they inhibited the plant from growing. When $\mathrm{Pb}$ concentration in soil was $3000 \mathrm{ppm}$, the $\mathrm{Pb}$ accumulation in shoots and roots were 202.9 and $2425.9 \mathrm{ppm}$, respectively. While As and $\mathrm{Cd}$ concentrations in the soil was $25 \mathrm{ppm}$, the content in shoots and roots were 185.6 and 228.9 ppm (for As); 185.6 and $228.9 \mathrm{ppm}$ (for $\mathrm{Cd}$ ), respectively. Brassica juncea can be used to remove $\mathrm{As}, \mathrm{Pb}$ and $\mathrm{Cd}$ concentration in contaminated soil but it should be noted that this plant also a popular green vegetable for people.

\subsubsection{Vetiveria zizanioides}

In soil contaminated with $\mathrm{Pb}$ from 1400.5 to $2530.1 \mathrm{mg} /$ $\mathrm{kg}$, Vetiveria zizanioides still grew well after 90-day treatment. Some charateristics of plant growing on $\mathrm{Pb}$ contaminated soil such as height, root length, biomass and the Chlorophyll concentration increased more than those on control soil (soil without $\mathrm{Pb}$ ). $\mathrm{Pb}$ concentration analysis in soil after this experiment showed that, the $\mathrm{Pb}$ extraction effect from the contaminated soil by Vetiveria zizanioides could reach from $87 \%$ to $92.6 \%$. However, the average $\mathrm{Pb}$ accumulation in its shoots and roots were not high being only 24 and 349 ppm, respectively. This species also can accumulate As and Cd taken from soil. Many our further experiment results showed that feasibility of using Vetiveria zizanioides as phytostabilization agent for $\mathrm{Pb}, \mathrm{Cd}$ and $\mathrm{As}$ in contaminated soils.

\subsubsection{Eleusine indica}

Eleusine indica can be used for remediating the soil contaminated with $\mathrm{Pb}$ and $\mathrm{Zn}$. Results of the survey showed that this plant can grow in the waste area of lead, zinc processing factory. Analyzing $\mathrm{Pb}$ and $\mathrm{Zn}$ concentration in soil and plants showed that if soil contained $4316.96 \mathrm{ppm} \mathrm{Pb}$, there would have 664.45 and $4638.17 \mathrm{ppm} \mathrm{Pb}$ in shoots and roots of the plant, respectively; if soil contained $1000 \mathrm{ppm} \mathrm{Zn}$, there would have 761.6 and $2011.3 \mathrm{ppm}$ in shoots and roots, respectively. Eleusine indica could grow well at the concentration of $\mathrm{Pb}$ and $\mathrm{Zn}$ in soil lower than 5000 and $1000 \mathrm{ppm}$, respectively.

\subsubsection{Pennisetum purpureum}

When $\mathrm{Pb}$ concentration in the soil was $3600 \mathrm{ppm}, \mathrm{Pb}$ accumulated levels in shoot and root of the plant were 164.3 and $1009.1 \mathrm{ppm}$, respectively. When $\mathrm{Cd}$ concentration in soil was $31.5 \mathrm{ppm}$, the Cd accumulated concentrations in shoot and root of the species were 5.7 and 320.1, respectively. Some other result showed that, the grass accumulated $\mathrm{Pb}$ and $\mathrm{Cd}$ mainly in roots and the plant grown in the soil with higher heavy metal concentration could accumulate them higher in their biomass.

\subsubsection{Pteris vittata and Pityrogramma calomelanos}

Two ferns Pteris vittata and Pityrogramma calomelanos can grow in the mining soil containing 15,146 ppm As. Although they are As hyperaccumulators, the plants still have ability to accumulate $\mathrm{Cd}, \mathrm{Pb}$ and $\mathrm{Zn}$. Pteris vittata and Pityrogramma calomelanos can tolerate 5000 and $4000 \mathrm{ppm} \mathrm{Pb} ; 1200$ and $300 \mathrm{ppm} \mathrm{Cd}$, respectively. The highest level of As accumulation in Pteris vittata and Pityrogramma calomelanos are 6042 and 4034 ppm (in the fronds); 3756 and 2256 (in the roots), respectively. From 3 to 4 months after growing there is appropriate time for harvesting biomass plants if applied in practical processing.

\section{Conclusion}

Base on the evaluating $\mathrm{Cr}$ and $\mathrm{Ni}$ tolerance of seven potential plant species, two plant species having a highest tolerance to $\mathrm{Cr}$ and $\mathrm{Ni}$ concentrations are Vetiveria zizanioides and Phragmites australis.

Screening research of 33 plant species in Thai Nguyen province indicated that two ferns Pteris vittata and Pityrogramma calomelanos were suitable for As treatment in the mining soil of Ha Thuong, Dai Tu district. Four grasses like Eleusine indica, Cynodon 
dactylon, Cyperus rotundus and Equisetum ramosissimum were the best in accumulating $\mathrm{Pb}, \mathrm{Zn}$ in their roots.

Other investigated plant species like Brassica juncea, Pennisetum purpureum, Vetiveria zizanioides were potential to remediate the soil contaminated with $\mathrm{As}, \mathrm{Cd}$, $\mathrm{Pb}$ and $\mathrm{Zn}$.

\section{Acknowledgments}

This research was funded by the Vietnam Academy of Science \& Technology (VAST) and Vietnam National Foundation for Science \& Technology Development (NAFOSTED).

\section{References}

[1] Bui Thi Kim Anh, Dang Dinh Kim, Tran Van Tua, Nguyen Trung Kien, Do Tuan Anh. 2011. Phytoremediation potential of indigenous plants from Thai Nguyen province, Vietnam. Journal of Environmental Biology 32: 257-262.

[2] Dang, T.A., Chu, T.T.H., Dao, T.C.T. 2007. Some characteristics of the flora in $\mathrm{Pb}$-, Cd-polluted areas in Tan Long, Dong Hy, Thai Nguyen. Proceedings of the 2nd National Scientific Conference on Ecology and Biological Resources, Hanoi 26 October 2007 (Sections of Fauna and Flora of Vietnam \& Ecology and Environment): 297-301 (in Vietnamese).

[3] Diep, T.M.H., Garnier, Z.E. 2007. Lantana camara $L$, - the plant species can accumulate $\mathrm{Pb}$ in the polluted soil. Science and Technology Development Journal 10(1): 35-38 (in Vietnamese).

[4] Ghosh, M., Singh, S.P. 2005. A review on Phytoremediation of heavy metals and utilization of its byproduct. Applied Ecology and Environmental Research 3(1): 1-18.

[5] Hemen, S. 2011. Metal hyperaccumulation in plants: A review focusing on phytoremediation technology. J. Environ.Sci. Technol 4 (2): 118-138.

[6] Le, D. 2005. Cu, Mn and Mo concentration in some main kind of soils in the south of Vietnam. Soil Science Journal 10:193-196 (in Vietnamese).

[7] Le, V.C., Tran, M.P., Le, V.L. 2008. Simultaneous removal of ammonium and arsenic from ground water by phytofiltration. Intern.Sci. Conference on "Chemistry for development and intergration, Sept.12-14/2008. Hanoi, Vietnam. Proceedings:
679-688 (in Vietnamese).

[8] Le, V.T. 2004. Mining exploitation and impact to the environment. Proceeding of mining technical science conference, the sixteenth. Cua Lo, 7/2004 (in Vietnamese).

[9] Nguyen, T.C., Tran, V.T., Dang, D.K., Do, T.A., Le, T.T. 2008. The study of $\mathrm{Pb}$ accumulation in polluted soil by Vetiver grass (Vetiveria zizanioides). Science and Technical Journal 46(6A): 26-26 (in Vietnamese).

[10] Raskin, I., Smith, R.D., Salt, D.E. 1997. Phytoremediation of metals: Using plants to remove pollutants from the environment, Curr. Opin. Biotechnol, 8(2): 221-226.

[11] Salt D.E., Blaylock M., Kumar P.B.A.N., Dushenkov V., Ensley B.D., Chet I. and Raskin I. 1995. Phytoremediation: A novel strategy for the removal of toxic metals from envrionmental using plants. Biotechnology, Vol. 13: 468-474.

[12] Tiberon Mineral Ltd, 2004. Environmental impact assessment report of Nui Phao project, Dai Tu, Thai Nguyen (in Vietnamese)

[13] Tran, C.T., Dang, T.A., Dao, T.K.H. 2005. Some first results on Phytoremediation. Soil Science Journal 23: 156-158 (in Vietnamese)

[14] Tran, V.T., Nguyen, D. T., Do, T.A., Nguyen, T.K., Tran, N.N. 2008. Treatment of $\mathrm{Ni}$ and $\mathrm{Cr}$ contained wastewater by root zone method. Journal of Science and Technology 46(6A): 40-45 (in Vietnamese).

[15] US EPA 3051 Method (1994). Microwave-assisted acid digestion of sediments, sludges, soils and oils (pp. 1-14). Technical Report, Washington, District of Columbia.

[16] TCVN 5945-2005. Discharge standards for industrial wastewater (in Vietnamese).

[17] Le, H.T. 2004. Seminar on "Current status of heavy metal pollution in Vietnam", Institute of Environment and Natural Resources, VNU HCM, 6 pages (in Vietnamese).

[18] Dang, D.K. 2010. Study on phytoremediation of heavy metal - contaminated soils in mining areas. National project KC08.04/06-10, (in Vietnamese)

[19] Dang, K.C., Nguyen, N.L., Tran, L. 2005. Vietnam craft village and environment, publishing by scientific and engineering, 391 pages. 